\title{
DINAMIKA PRAKTIK JURNALISME WARGA MELALUI MEDIA BARU
}

\author{
Ananda Dwitha Yuniar \\ Fakultas Ilmu Sosial, Prodi Ilmu Komunikasi, Universitas Negeri Malang \\ Jalan Semarang No. 5 Malang \\ No. Telp./HP: 087850143342 \\ E-mail: anandadwitha24@gmail.com
}

\begin{abstract}
ABSTRAK
Perkembangan media baru melahirkan potensi yang mendorong praktik pelaporan berita oleh warga biasa. Krisis ruang publik dalam media arus utama, membuat teknologi media baru menjadi jawaban untuk merevitalisasi kembali kesempatan warga yang telah didominasi oleh pemilik modal. Media baru telah menyediakan ruang seluas-luasnya bagi warga negara untuk terlibat dalam proses penyampaian berita ataupun informasi. Keterlibatan ini juga didukung dengan berkembangnya citizen media atau media warga yang merupakan perpanjangan dari media arus utama seperti Kompasiana milikKompas dan NET CJ milik Netmediatama. Namun, trend jurnalisme warga ini masih menjadi pertanyaan apakah mengarah kepada manifestasi demokrasi atau malah menimbulkan masalah baru berkaitan dengan kredo jurnalisme? Penelitian ini merupakan penelitian kualitatif menggunakan analisa deskriptif. Pengumpulan data berupa studi dokumentasi praktikpraktik jurnalisme warga yang ada pada website NET CJ danKompasiana. Penelitian ini juga menggunakan literatur review dengan penelitian sejenis untuk menguatkan argumen dan analisa. Hasilnya, ada beberapa kendala pula terkait praktikjurnalisme warga di Indonesia terutama pada media Kompasiana terkait kredojurnalisme yang benar tentang objektifitas dan etika sehingga kini masih menjadi perdebatan apakah produk buatan warga ini dapat disebut sebagai produk jurnalistik
\end{abstract}

Kata kunci: media baru, jurnalisme warga, media warga, parsipasi publik

\section{ABSTRACT}

The rise of new media and ubiquitos of technology encourages the practice of news reporting by citizens. Public space crisis in mainstream media, making new media elucidate to revitalize the opportunities that citizens be apart of social changes. The new media has provided the widest space for citizens to engage in the delivery of news or information. This involvement is also supported by the development of citizen media or which is an extension of mainstream media such as Kompasiana owned by Kompas and NET CJ owned by Netmediatama. However, the trend of citizen journalism is still a question of whether to lead to the manifestation of democracy or even cause new problems related to journalism credo? This research is a qualitative research using descriptive analysis. Data collection using documentation study of citizen journalism practices that exist on NET CJ and Kompasiana website. This study also uses literature review with similar research to strengthen arguments and analysis. As a result, there are also several obstacles related to the practice of citizen journalism in Indonesia, especially in Kompasiana media related to the correct credentials of journalism about objectivity and ethics so that it is still being debated whether these products made by citizens can be called journalistic products.

Keywords: new media, citizen journalism, citizen media, public participatory 


\section{A. PENDAHULUAN}

Bukan menjadi isu baru bahwa kinerja jurnalis pada media arus utama telah banyak menuai kritik karena kecenderungan bias pemberitaannya. Peran media sebagai institusi sosial sering kali bertolak belakang disebabkan adanya kepentingan pemilik yang berafiliasi ekonomi dan politik. Seperti argumentasi yang disampaikan oleh McChesney and Nichols (2010) bahwa krisis terhadap kinerja jurnalisme disebabkan karena mereka bekerja dibawah institusi media yang berorientasi laba dan mengarah kepada komersialisasi. Sementara itu, di negara yang menganut sistem demokrasi membutuhkan warga negara yang wellinformed atau terinformasi dengan baik. Sumber informasi ataupun berita untuk warga harus substantif dan berkaitan dengan kepentingan mereka. Selain itu, sebagai negara demokrasi seharusnya memberikan kesempatan kepada warga negara untuk terlibat dalam mengemukakan gagasan tanpa adanya tekanan dari pihak manapun.

Pada kenyataannya, media arus utama khususnya televisi sudah jauh dari perwujudan nilai demokrasi karena konten yang ditampilkan selalu mengarah kepada kepentingan elit. Krisis ruang publik dalam media arus utama, membuat teknologi media baru menjadi jawaban untuk merevitalisasi kembali kesempatan warga yang telah didominasi oleh pemilik modal. Media baru sebagai teknologi yang memungkinkan komunikasi secara digital melalui computer mediated communication (Creeber dan Martin, 2009, p.2). Komunikasi secara digital ini dapat dilakukan pengguna untuk membuat konten mereka sendiri usergenerated-content (UGC) melalui teknologi berbentuk blog seperti Wordpress, Tumblr, dan Blogspot, selain itu ada microblogging seperti Twitter dan Facebook, kemudian UGC berbasis video melalui media Youtube. Potensi media baru yang memungkinkan pengguna membuat kontennya sendiri kemudian mendorong pengguna secara aktif (participatory) dalam pembuatan dan diseminasi konten secara global.

Potts, dkk (2008) menjelaskan konsep 'participatory' sebagai proses di mana audiens terlibat aktif dalam proses menjadi producer (pembuat) sekaligus consumer (pengguna) yang disingkat sebagai prosumer. Prosumer ini sekaligus merubah value yang dimiliki oleh audiens yang sebelumnya hanya bertindak sebagai pengguna, dengan adanya kolaborasi maka audiens juga dapat membuat produk sesuai preferensi dan minatnya sendiri (Zwick, dkk, 2008). Melalui kolaborasi prosumer ini, banyak ilmuwan dari beberapa negara begitu optimis menyatakan bahwa perkembangan ini memberi warga negara lebih banyak kekuatan dalam proses pengumpulan dan diseminasi informas, (Allan, 2009, p. 18).

Banyaknya media yang memfasilitasi kebebasan prosumer dalam masyarakat, kemudian mengarah ke bidang jurnalisme. Kegiatan jurnalisme atau pelaporan berita yang sebelumnya dilakukan oleh profesi wartawan kini dapat dilakukan oleh warga biasa tanpa skill. Spekulasi yang disampaikan oleh Cooper (2006) bahwa masyarakat yang mengilhami praktik jurnalisme tersebut sebagai manifestasi asas demokrasi dan menurunnya kepercayaan mereka atas media arus utama. Selain itu, menurut Carr, dkk (2014) praktik jurnalisme yang dilakukan oleh warga muncul sebagai respon terhadap krisis dan lemahnya peran jurnalis dalam memuat konten-konten berita yang homogen. Hadirnya media baru membuat warga dapat memahami dan terlibat secara aktif terkait isu-isu yang beredar di masyarakat sehingga berita yang dihasilkan lebih beragam. Berdasarkan latar belakang inilah kemudian muncul dan secara continue menjadi trend pembuatan berita oleh warga yang biasa disebut sebagai jurnalisme warga.

Penjelasan mengenai jurnalisme warga disampaikan oleh Bowman dan Willis (2003) yaitu tindakan yang dilakukan oleh warga baik individu ataupun kelompok yang berperan aktif dalam proses mengumpulkan, melaporkan, menganalisa, dan menyebarkan berita dan informasi. Allan (2013) kemudian menambahkan bahwa siapa saja dengan ponsel yang terhubung dengan internet di waktu dan 
tempat kejadian berita maka mereka dapat disebut jurnalis. Secara lebih sederhana inferensi dari kedua pengertian tersebut adalah warga yang dulu hanya sebagai pengkonsumsi berita, namun sekarang mereka dapat menjadi pemilik informasi yang dibagikan kepada banyak orang. Pergesaran peran dari hanya sekadar pengonsumsi menjadi sumber berita itu sendiri dimotori oleh perkembangan media yang memfasilitasi dan mengakomodasi penyampaian berita (citizen media).

Di Indonesia, beberapa media arus utama telah mengakomodasi praktik jurnalisme warga seperti media Kompasiana yang merupakan milik Kompas, media Indonesiana milik Tempo, Pasang Mata milik Detik, NET CJ milik Net Mediatama, dan sebagainya. Berbagai jenis media jurnalisme warga di Indonesia yang telah disebutkan diatas memang tidak ada yang terbentuk secara independen, semua merupakan perpanjangan dari media arus utama. Praktik jurnalisme warga sesungguhnya terjadi pada media jurnalisme warga Oh My News! yang populer di Korea Selatan. Oh My News telah terkenal secara global sebagai media yang mengakomodasi pemberitaan jurnalis warga tanpa tendensi atau keterkaitan dengan media arus utama. Secara singkat, Oh My News dibentuk secara independen dan telah memiliki standar yang diatur sedemikian rupa untuk mengarahkan jurnalis yang berasal dari waga biasa membuat konten yang berkualitas. Selain itu, praktik jurnalisme warga independen juga ada di Thailand bernama ThaiPBS yang dibentuk oleh sekelompok individu yang tergerak untuk melegitimasi hak publik akan pemberitaan (Boonlert, 2014).

Pada makalah ini, penulis akan mengerucutkan pembahasan mengenai praktik jurnalisme warga di Indonesia yang terjadi pada Kompasiana dan NET CJ. Pemilihan objek Kompasiana pada pembahasan makalah ini karena media ini merupakan pelopor media jurnalisme warga di Indonesia berbasis Web Blog. Selain itu, Kompasiana juga sering mengalami permasalahan terkait konten berita yang dimuat oleh warga. Padahal, informasi-informasi yang disampaikan oleh para kompasianer tetap banyak dibaca dan sering menjadi rujukan oleh pembaca. Hal ini dapat dilihat pada blog Kompasiana dimana jumlah pembaca sebuah tulisan bisa mencapai ribuan. Selain itu, menurut data Alexa Inc (2016) Kompasiana yang diluncurkan tahun 2008 ini telah menjadi media jurnalisme warga terbesar di Indonesia dengan jumlah visitor rata-rata 264.140 perhari.

Sedangkan, pemilihan pengangkatan media jurnalisme warga NET CJ dengan jargon 'everybody can be a journalist' ini karena media ini mengakomodasi pemberitaan warga dalam bentuk narasi disertai usergenerated content video. Selain itu, NET CJ juga memberikan kesempatan bagi warga Indonesia memuat berita mulai dari dalam negeri hingga manca negara yang di unggah pada website netcj.co.id. Kemudian, beberapa berita buatan warga ini akan ditayangkan pada media arus utama televisi yang ditonton jutaan pasang mata, itu sebabnya penting untuk mengetahui bagaimana praktik jurnalisme warga pada NET CJ.

Pembahasan makalah ini juga akan melihat bentuk-bentuk pelaporan berita yang dilakukan oleh warga beberapa bulan terakhir apakah telah sesuai dengan kaidah jurnalisme. Karena menurut Allan (2013) kehadiran jurnalisme warga mampu merubah standar dalam pelaporan berita, hal ini dikarenakan praktik jurnalisme warga merupakan bentuk aspirasi dan kritisi terhadap hal-hal yang dianggap tidak benar. Namun, disisi lain menurut Hernida dan Thurman (2008) praktik jurnalisme warga merupakan wujud dari nilai demokrasi atas potensi kebebasan berpendapat. Melalui kedua pernyataan tersebut dapat ditemukan gap yang dirumuskan dengan pertanyaan :

1. Bagaimana praktik jurnalisme wzarga di Indonesia, apakah mengarah kepada manifestasi demokrasi atau malah menyebabkan perubahan kredo jurnalisme terkait nilai berita?

2. Bagaimana dampak yang akan terjadi bila jurnalisme warga tidak sesuai 
dengan kredo jurnalisme sebagaimana berlaku di media arus utama?

\section{B. LANDASAN TEORI}

\section{Potensi Media Baru terhadap Partisipasi Warga}

Seperti yang telah disinggung di atas, media arus utama khususnya televisi sudah jauh dari perwujudan nilai demokrasi karena konten yang ditampilkan selalu mengarah kepada kepentingan elit. Krisis ruang publik dalam media arus utama, membuat teknologi media baru semakin menampakkan transformatifnya. Media baru merupakan terminologi atas jawaban untuk merevitalisasi kembali kesempatan warga yang telah didominasi oleh pemilik modal. Creeber dan Martin (2009) kemudian menjelaskan bahwa media baru sebagai teknologi yang memungkinkan komunikasi secara digital melalui computer mediated communication. Media baru ini kemudian memunculkan potensi kepada warga negara untuk terlibat secara aktif atau dikenal dengan istilah participatory dalam pembuatan dan diseminasi konten secara global.

Potts, dkk (2008) menjelaskan konsep 'participatory' sebagai proses di mana audiens terlibat aktif dalam proses menjadi producer (pembuat) sekaligus consumer (pengguna) yang disingkat sebagai prosumer. Kolaborasi ini tentunya memberikan peluang warga negara yang biasanya hanya sebagai pengguna, dapat terlibat secara langsung menuangkan denya melalui user-generated-content.

Participatory in dapat dilakukan melalui teknologi media baru berbentuk blog seperti Wikipidea dan Wordpress yang dapat memfasilitasi siapa saja untuk menyunting, menghapus, dan juga menambahkan konten (Jurrat, 2011). Selain itu ada microblogging atau media sosial seperti Twitter dan Facebook yang dapat digunakan untuk berbagi pengalaman pribadi. Kemudian user-generatedcontent berbentuk video melalui Youtube. Dengan demikian, penonton tidak hanya terhubung secara vertikal dengan orangorang yang memiliki kekuatan seperti editor dan politisi, tetapi juga secara horisontal yang memberikan mereka peluang dalam memobilisasi konten (Rosen, 2006).

\section{Media Arus Utama sebagai Akomodasi Jurnalisme Warga}

Munculnya media yang memfasilitasi kebebasan pengguna untuk memproduksi kontennya sendiri (user generated content) kemudian mengarah ke bidang jurnalisme Terlahir dari krisis kredibilitas pada media arus utama, warga negara mengaku bisa menyelesaikan masalah apa yang dilihatnya sebagai sebuah berita (Nichols dkk., 2006). Kegiatan jurnalisme yang sebelumnya dilakukan oleh wartawan profesional kini dapat dilakukan oleh masyarakat biasa. Hal ini juga disampaikan oleh Glaser (2006) bahwa konsep jurnalisme warga atau 'participatory journalism' telah digunakan untuk menyampaikan gagasan warga baik secara individu ataupun kolaborasi menggunakan teknologi untuk melakukan distribusi fakta secara global tanpa pelatihan profesional jurnalistik. Pada intinya jurnalisme warga mendorong partisipasi aktif dari warga dalam proses membuat sebuah berita yang mereka lihat dan alami tanpa literasi yang cukup.

Di Indonesia, beberapa media arus utama telah mengakomodasi praktik jurnalisme warga seperti media Kompasiana yang merupakan milik Kompas, media Indosiana milik Tempo, Pasang Mata milik Detik, NET CJ milik Net Mediatama, dan sebagainya. Namun, berbagai jenis media jurnalisme warga di Indonesia yang telah disebutkan di atas memang tidak ada yang terbentuk secara independen, semua merupakan perpanjangan dari media arus utama. Berdasarkan penelitian yang dilakukan oleh Macharashvili (2012) ada banyak keunggulan bagi media arus utama yang mengakomodasi praktik jurnalisme warga antara lain minimalisir biaya, memberikan masyarakat kesempatan dalam mewujudkan demokratisasi, berita lebih bervariasi terutama konteks lokal, tidak ada 
akuntanbilitas, dan dapat menjadi alternatif bagi wilayah yang tidak terjangkau.

Tampaknya kolaborasi yang dilakukan media arus utama yang mengakomodasi jurnalisme warga sebagai bagian dari kegiatan jurnalisme mampu menimbulkan hubungan simbiosis mutualisme. Boonlert (2014, p. 2) menyatakan :

"New media technologies, particularly the Internet, media-sharing websites and the increasing prevalence of mobile phones have made citizen journalism more accessible to people all over the world, who can often report news stories much faster than mainstream media".

Penjelasan ini menyiratkan institusi media dapat memanfaatkan keberagaman dan kecepatan konten yang diunggah oleh warga negara melalui teknologi media baru. Selain itu, Becket (2010) juga menyatakan bahwa jurnalisme warga dapat menambah kualitas produksi berita dengan menjadikan jurnalisme semakin beragam. Sedangkan keuntungan bagi warga, mereka dapat turut serta dalam menuangkan gagasan dan konten sebagai wujud demokrasi suatu bangsa.

Bentuk kerja sama antara praktik jurnalisme warga dan jurnalisme media arus utama ini disebut sebagai Journalism Hybrid (Kusumaningati, 2012). Kehadiran jurnalisme warga yang begitu berkesan dan memilikı nilai berita adalah pada saat terjadi bencana tsunami dan gempa bumi di Aceh yang begitu cepat tersebar melalui internet dan berhasil mendatangkan bantuan nasional dan internasional bagi korban bencana tersebut. Inilah fungsi dari jurnalisme itu sendiri melaporkan kejadian newsworthy terkait bencana ataupun krisis sebelum media arus utama tiba di tempat kejadian (Allan, 2009).

\section{METODE PENELITIAN}

Penelitian ini merupakan penelitian kualitatif menggunakan analisa deskriptif. Pengumpulan data berupa studi dokumentasi praktik-praktik jurnalisme warga yang ada pada website NET CJ dan Kompasiana pada tahun 2017. Penelitian ini menggunakan teknik literature review dengan penelitian sejenis untuk menguatkan argumen dan analisa.

\section{HASIL DAN PEMBAHASAN}

\section{Bentuk Participatory Journalism Kompasiana}

Kompasiana adalah sebuah platform publikasi online yang dikembangkan oleh Kompas Gramedia sejak 2008. Kompasiana menjadi media warga yang hadir lebih awal sebagai pelopor kegiatan jurnalisme warga berbasis blog. Pengguna yang telah memiliki akun dan mengunggah setiap konten (artikel, foto, komentar) disebut Kompasianer. Data Alexa, Inc (2016) menunjukkan Kompasiana telah menjadi media warga terbesar di Indonesia dan memiliki jumlah visitor view 140.500 perhari. Namun, penulisan berita yang dilakukan kompasianer sering terganjal oleh masalah etika dan profesional.

Beberapa berita yang diposting oleh Kompasianer cenderung subjektif dan ratarata membuat berita berupa opini, tulisan ringan, dan tidak mengandalkan data atau fakta yang valid. Bahkan, beberapa berita yang di posting oleh warga juga bermuatan SARA seperti yang diposting oleh Nurdin Taher "Ahok Memang Menistakan Agama, Dimas Kanjeng Tidak!" update 09 Oktober 2016.

Pemostingan berita oleh kompasianer ini begitu provokatif dan menurut asumsi penulis cenderung tidak masuk akal karena mengedepankan negatif emosional. Bahkan, ia juga menulis kata-kata rasis dengan mengatakan 'china lagi kapir'. Tak selang waktu lama kemudian Daniel $\mathrm{H}$. T. "Rizieq Shihab Juga Pernah Ingatkan Umatnya Jangan Sampai Dibohongi Pakai Ayat Al-Qur'an" berita 08 November 2016. 


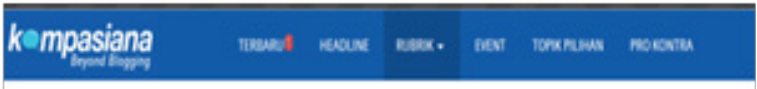

Ahok Memang Menistakan Agama, Dimas Kanjeng Tidak!

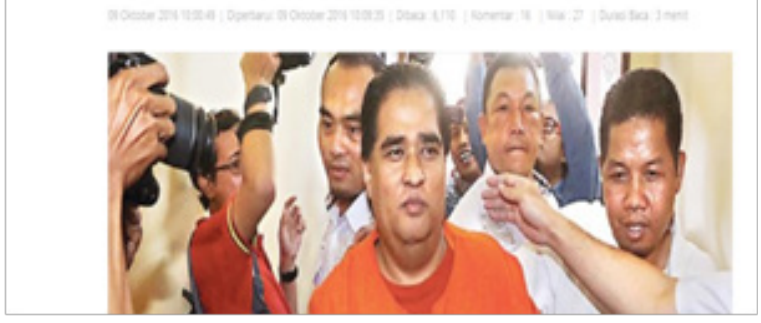

Taat Pribadi boleh membuat geger, tapi Ahok menang tidak boleh. Apapun alasan konstitusionalnya, Ahok yang China lagi kapir ini, tidak boleh mengatakan apa-apa tentang hal yang berkaitan dengan isu agama. Meski isu yang dikomentari Ahok itu merupakan reaksi balik terhadap aksi provokasi yang selama ini ditujukan kepadanya. Celakanya, sudah menjadi sasaran tembak, Ahok dipaksa pula harus meminta maaf, bahkan dilaporkan ke polisi atas tuduhan penistaan agama.

Sumber: http://kompasiana.com/

Gambar 1. Praktik jurnalisme warga pada Kompasiana

kompasiana

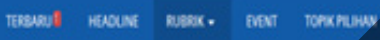
Rizieq Shihab Juga Pernah Ingatkan Umatnya Jangan Sampai Dibohongi Pakai Ayat Al-Quran

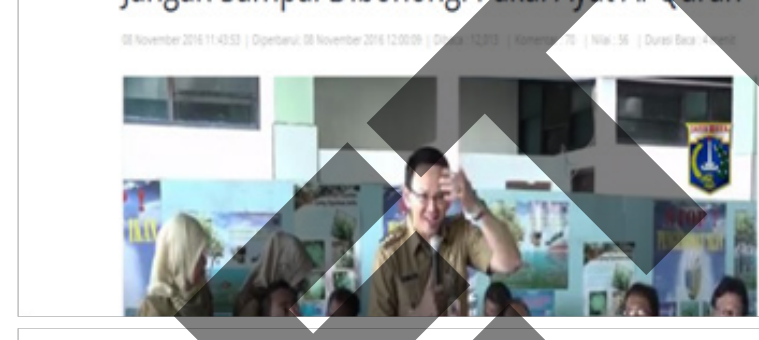

Ahok masih waras, ia sangat membutuhkan suara warga DKI Jakarta yang

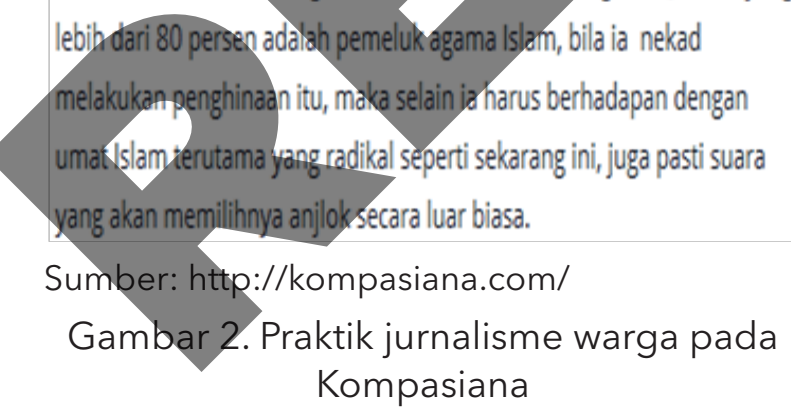

Berita yang dimuat ini menimbulkan tendensi dan seakan mengeneralisasikan bahwa agama islam adalah agama yang radikal 'umat Islam terutama yang radikal ini'. Kedua dari sekian banyak artikel yang ditulis dalam media Kompasiana, berbicara tanpa memiliki data dan fakta dan mengandalkan subjektivitas. Pembuat artikel bukan sematamata untuk memenuhi kebutuhan informasi publik tetapi lebih kepada aktualisasi diri dalam menyampaikan pandangan ataupun opini tentang apa yang mereka anggap benar. Selain itu mereka belum sepenuhnya terliterasi bagaimana menyajikan berita ataupun informasi seperti yang dilakukan oleh wartawan profesional. Lecheler and Kruikemeier (2016, p. 159) mengungkapkan bahwa literasi dalam pemostingan berita pada media digital merupakan hat yang sentral dalam kegiatan jurnalisme pada media online. Perlunya literasi digital adałah untuk menghindari gesekan yang dapat memecah belah persatuan.

Lantas apakah citizenyang mengunggah hanya berdasar opini ataupun subjektifitas seperti yang dilakukan oleh kompasianer di atas bisa disebut jurnalis? Menurut asumsi penulis sendiri tidak bisa, karena masyarakat bukan jurnalis profesional ataupun bukan ingin menjadi jurnalis. Jurnalis profesional memiliki kode etik ataupun kredo dalam proses pemuatan berita, namun belum ada aturan tertulis untuk kaidah penulisan oleh kegiatan pewarta warga. Para citizen yang melanggar kaidah jurnalisme juga tidak bisa dianggap melanggar kode etik jurnalistik, karena KEJ yang disahkan oleh Dewan Pers merupakan milik para pekerja yang berprofesi jurnalis. Seperti yang dikemukakan oleh Phillips (2015, p.48) berbeda dengan praktik pewarta warga yang mengedepankan opini dan subjektifitas, profesi jurnalis memang telah terlatih dan wajib menerapkan authoritative dengan menyajikan data dan fakta terhadap apa yang ditulis dan dilaporkan kepada publik.

Kompasiana telah jelas dalam membuat kebijakan bahwa kompasianer diberi kebebasan untuk mengemukakan, mengekspresikan, serta menyampaikan informasi, gagasan, pendapat, ulasan, ataupun tanggapan, sepanjang dapat dipertanggungjawabkan sesuai dengan norma dan hukum yang berlaku di Indonesia. Selain itu, Kompasiana juga telah mengatur 
kebijakan terkait konten, layanan, hak cipta, pelaporan konten, dan Undang-undang ITE No. 19 Tahun 2016. Bagi kompasianer ataupun pewarta warga yang memuat berita dengan sengaja menimbulkan hoax ataupun unsur SARA sudah diatur hukumnya tepatnya pada pasal 45A. Dengan adanya regulasi seperti ini diharapkan para warga negara yang melakukan diseminasi berita melalui media online lebih berhati-hati dan menciptakan kedamaian.

Namun, tidak menutup kemungkinan bahwa ada beberapa kompasianer yang masih menerapkan fungsi jurnalisme warga itu sendiri dengan baik dan bersifat informatif. Seperti artikel kompasianer berjudul 'adiknya disurga kebanggan kita' terkait korban meninggal akibat ledakan bom di Terminal Kampung Melayu, Jakata. Korban merupakan seorang polisi berpangkat bripda yang berasal dari Lampung. Berita yang dimuat oleh kompasianer ini kemudian tampil di media arus utama website sekaligus Kompas TV yang telah mengirimkan kontributor beritanya ke lokasi kejadian. Kejadian yang diunggah oleh kompasianer ini kemudian menimbulkan banyak simpati yang ditujukan kepada keluarga korban. Tak hanya itu, apresiasi juga diberikan oleh Presiden Jokowi dan beberapa petinggi polri atas keberanian korban yang sedang bertugas di lokasi kejadian sebelum akhirnya dinyatakan meninggar.

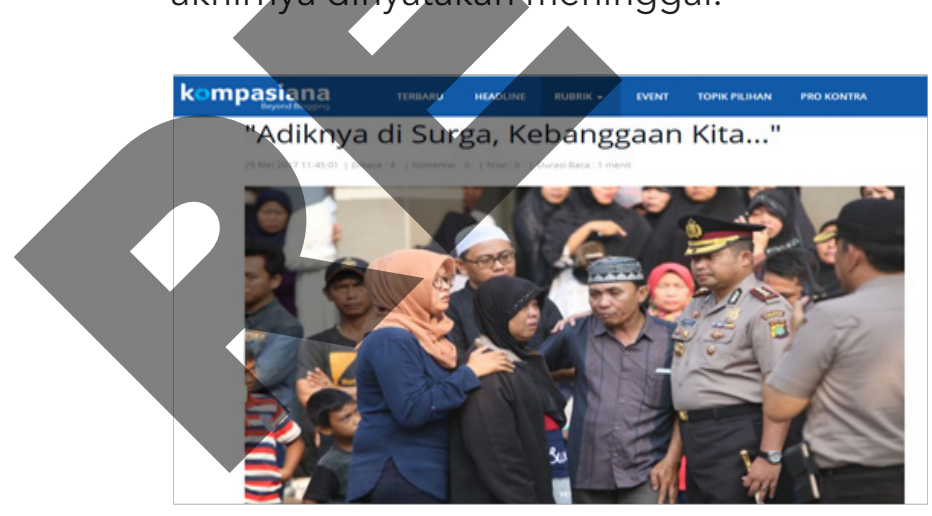

Sumber: http://kompasiana.com/

Gambar 3. Praktik jurnalisme warga pada Kompasiana

Meski sering terganjal masalah etika dan profesional, namun informasi-informasi yang disampaikan oleh para pewarta warga tetap banyak dibaca dan sering menjadi rujukan oleh pembaca. Hal ini dapat dilihat misalnya pada sosial blog Kompasiana dimana jumlah pembaca sebuah tulisan bisa mencapai ribuan (keterangan : dibaca), dan jumlah orang yang memberikan komentar (keterangan :komentar) yang meng-sharekan (keterangan : share on Facebook; share on Twitter) tulisan tersebut juga tidak sedikit. Apalagi jika informasi tersebut banyak mendapatkan komentar dan dibaca orang lain, maka akan menjadi tutisan yang masuk di indeks terekomendasi artinya tulisan tersebut direkomendasikan oleh admin Kompasiana untuk dibaca karena penting untuk diketahui oleh masyarakat. Bahkan tidak sedikit tulisan-tulisan di Kompasiana jika dinilai baik dan memenuhi syarat akan dimuat pada media arus utama Kompas atau Kompas.com.

\section{Bentuk Journalism Participatory NET CJ}

Berbeda dengan Kompasiana yang mengakomodasi praktik jurnalisme warga dalam bentuk blog, NET CJ memanfaatkan potensi media baru sebagai praktik jurnalisme warga dalam bentuk video dan naskah. Konten berita yang diunggah oleh warga ini kemudian diseleksi, dan beberapa berita terbaik pilihan redaksi akan tayang di televisi pada program acara NET10. Menurut kebijakan, berita terbaik pilihan redaksi layak tayang jika konten yang dikirimkan oleh warga memiliki nilai berita dan kebaruan. Selain itu, pemilihan berita yang layak tayang di NET10 juga dilihat melalui kualitas gambar dalam pengambilan video. Sekilas melihat laman website NET CJ, konten yang dikirimkan oleh warga lebih mendominasi mengenai featurenews atau softnews. 

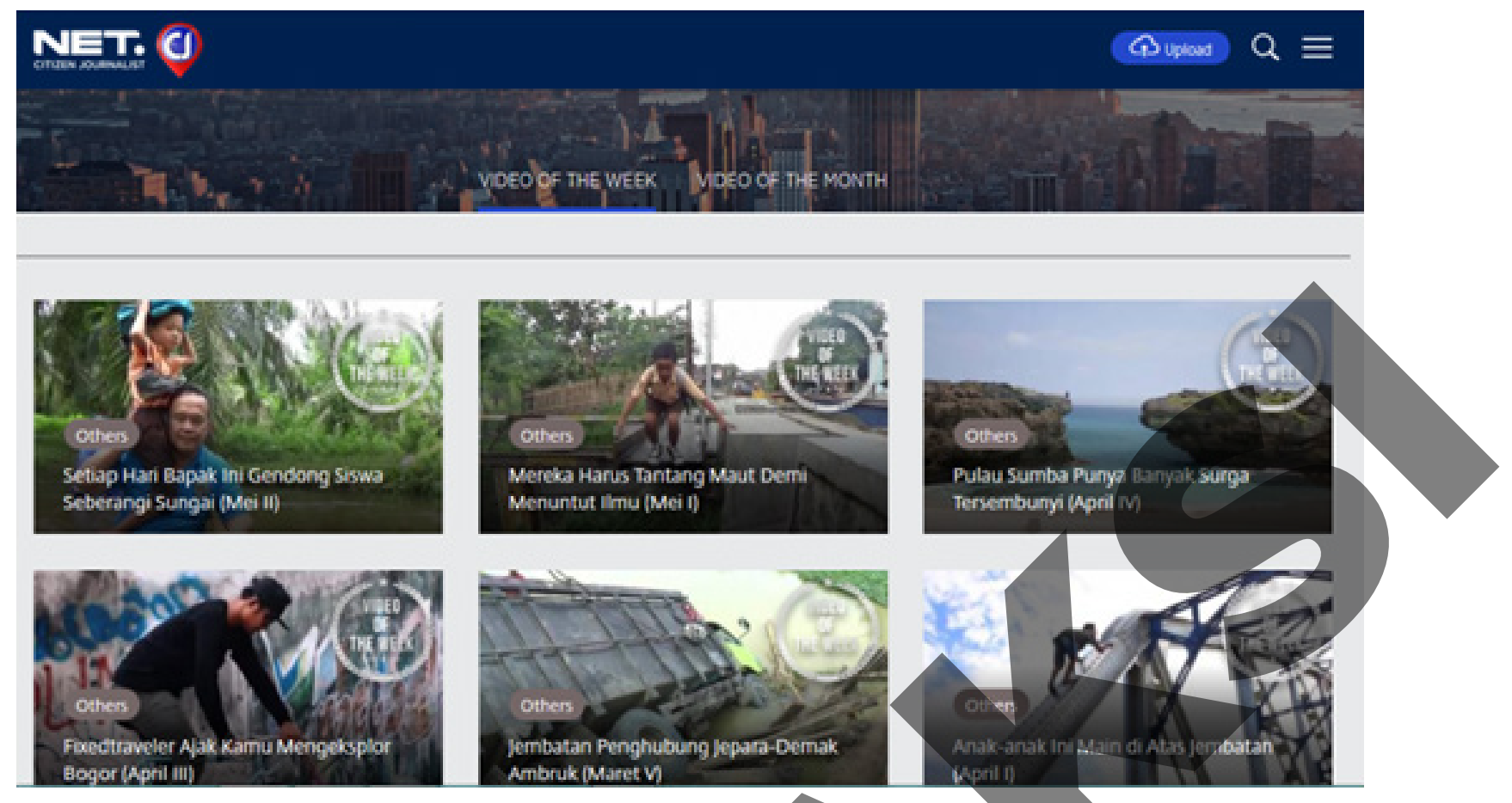

Sumber: http://netcj.co.id/

Gambar 4. Praktik jurnalisme warga berbentuk feature news

NET telah mengakomodasi jurnalisme warga selama 4 tahun sejak Mei 2013. Tak dapat dipungkiri, bahwa NET terbantu dengan adanya jurnalisme warga khususnya pada program NET 10 tayang selama 1 jam, hampir seratus persen konten beritanya berasal dari kiriman warga. Proses penayangan konten jurnalisme warga ke media arus utama melalui proses editing video dan juga naskah untuk menyesuaikan waktu tayang pada NEF 10. Walaupun demikian, NET tetap akan selalu mencantumkan nama pengirim video, dan bagi warga yang videonya berhasil tayang di televisi akan mendapatkan royalti yang sesuai. Sedangkan konten warga yang tidak tayang pada media arus utama, hanya akan ditampilkan pada website NET CJ.

Konten video yang diunggah pada media NET CJ oleh warga kebanyakan berkaitan dengan isu lokal seperti adat budaya, potensi sumber daya alam, tempat wisata dan sebagainya. Hal ini akan memberikan warna baru dan heterogenisasi konten dalam jurnalisme di mana telah susah ditemukan dalam media arus utama. Selain itu, konten lokal akan membawa nilai positif tentang keberagaman di negara Indonesia, yang biasanya tidak terjangkau oleh profesional jurnalis. Dengan adanya jurnalisme warga, beragam potensi lokal akan memperkaya wawasan di berbagai daerah di Indonesia.

Tak hanya konten lokal yang dieksplorasi oleh warga dalam bentuk berita, beberapa warga negara di Indonesia yang sekedar berlibur ataupun tinggal diluar negeri juga turut berpartisipasi dalam membagikan konten mereka. Seperti yang dilakukan oleh Rian beberapa hari lalu yang mengunggah video wisata di Filipina. la bertindak selayaknya seorang reporter/ jurnalis. Hal ini membuktikan bahwa kegiatan jurnalis bisa dilakukan oleh warga dimana saja kapan saja selama mereka memiliki peralatan yang memadai. Tak hanya itu, beberapa saat yang lalu warga mengunggah berita sekaligus terkait dengan penyambutan bulan ramadhan di Inggris. Walaupun islam menjadi agama minoritas, tetapi penyambutan bulan suci ramadhan tetap dilakukan. Berikut kedua cuplikan gambar yang diambil dari website NET CJ. 


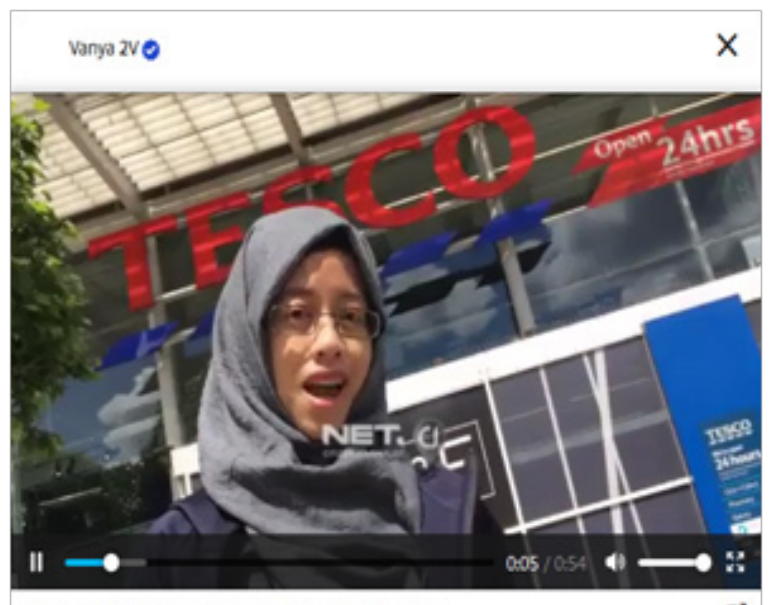

Supermarket di Ingoris juga llut Sambut Ramadan

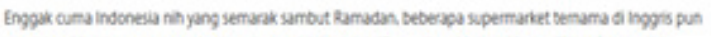

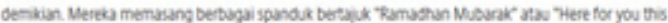

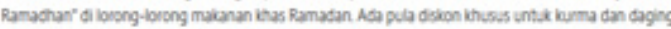

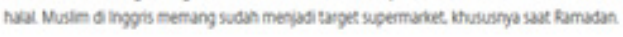

08.

kian Tangkepadang $O$

X

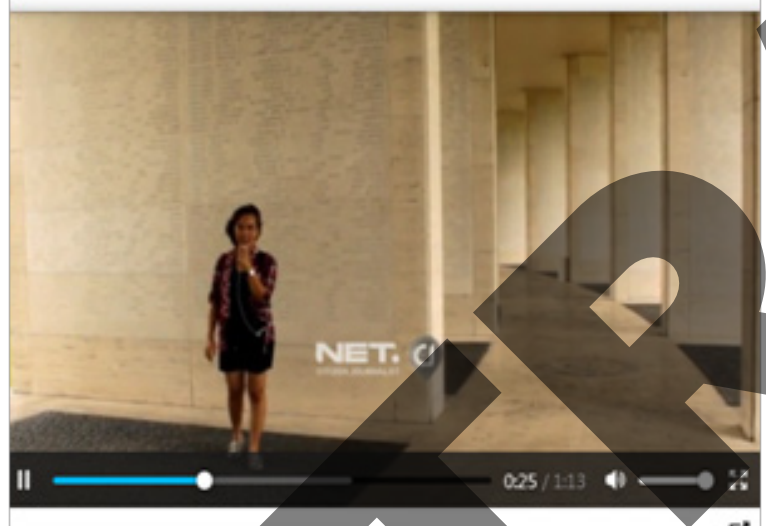

ธ

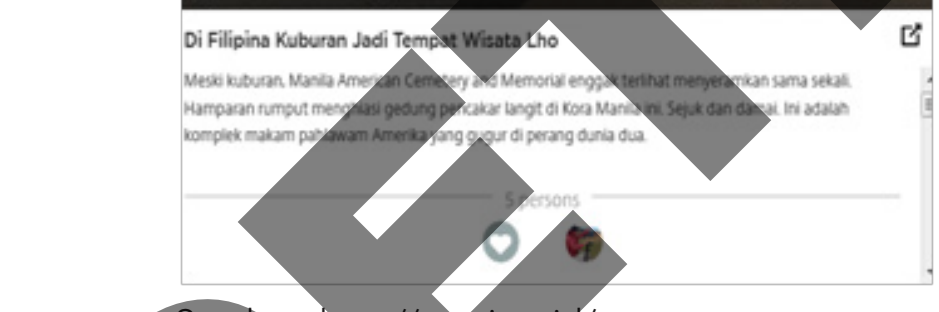

Sumber: http://netcj.co.jd/

Gambar 5 : Praktikjurnalisme warga pada media NET CJ

Kegiatan jurnalisme bisa dilakukan oleh siapa saja dimana selama mereka memiliki konten yang bernilai berita. Tetapi kembali lagi bahwa warga bukan profesi jurnalis, mereka tidak mendapat pelatihan ataupun tidak di bawahi oleh etika jurnalistik. Namun, bukan berarti bahwa warga tidak mampu membuat konten yang memiliki nilai berita. NET CJ telah mengakomodasi praktik jurnalisme warga yang baik dan benar.
Selain itu, NET CJ juga telah melengkapi aturan pembuatan konten melalui pedoman media siber. Hal ini yang memungkinkan NET CJ dapat memberikan kesempatan warga untuk melakukan praktik jurnalisme yang positif sesuai dengan asas demokrasi.

\section{Dinamika dan Implikasi Praktik Jurnalisme Warga}

Melalui apa yang telah disampaikan di atas, praktik jurnalisme di Indonesia membawasejumlahimplikasidalamcakupan yang luas. Pertama, adanya keterbukaan dalam proses pembuatan dan pelaporan berita hal initerkaitdengan adanya prosumer sehingga pembuatan berita tidak hanya dilakukan oleh profesional jurnalis. Tetapi dapat dilakukan oleh masyarakat biasa yang tidak memiliki literasi dan skill yang cukup terkait proses jurnalisme. Adanya prosumer ini kemudian juga mengaburkan batasan antara produsen dan konsumen. Media arus utama yang semula memosisikan diri sebagai produsen berita, kini juga menjadi konsumen berita dengan menyunting berita buatan warga. Demikian pula sebaliknya, warga yang biasanya diposisikan sebagai konsumen berita, dalam lingkup citizen journalism menjadi produsen berita yang kontennya dijadikan sumber oleh media arus utama.

Kedua, terkait tentang isu profesionalisme masih menjadi perdebatan di berbagai literatur tentang posisi warga dalam partisipasinya membuat berita. Apakah setiap pelaku jurnalisme warga bisa disebut wartawan? Karena pada kenyataannya slogan NET CJ everybody can be a journalist!. Selain itu Allan (2013) juga menyatakan bahwa siapa saja dengan ponsel yang terhubung dengan koneksi internet ditempat yang salah tapi berada diwaktu yang tepat 'wrong place at the right time' adalah jurnalis. Namun, berbeda dengan apa yang diungkapkan oleh Lewis, dkk (2010) yang menyatakan bahwa terpaan berita dalam teknologi internet membuat masyarakat menjadi bingung mana berita yang dapat di percaya, bahkan jika praktik jurnalisme itu berkualitas sekalipun, masyarakat akan ragu untuk percaya. 
Profesionalisme dalam praktikjurnalisme warga iini kemudian mengarah pada implikasi ketiga yaitu etika. Pertanyaannya apakah setiap pelaku jurnalisme warga perlu mematuhi standar-standar jurnalisme yang berlaku pada profesional jurnalis selama ini sehingga produknya layak disebut sebagai karya jurnalistik?. Berbeda dengan media arus utama yang menyajikan berita ataupun konten homogen dan lebih mengarah kepada kepentingan elit, media baru memang memberikan warna baru dalam proses jurnalisme. Sejak adanya jurnalisme warga, pemberitaan semakin beragam, potensi-potensi lokal terekspose, dan kejadian-kejadian spontan dapat menjadi berita yang menarik. Namun, tidak jarang terjadinya pelanggaran etika terkait tentang kredibilitas dan objektifitas. Seperti yang sering terjadi pada Kompasiana, banyak sekali warga yang belum bijak dalam memuat berita. Berita yang ditampilkan cenderung kepada opini yang tidak berdasarkan data dan fakta.

Hal tersebutjuga akan berkaitan dengan implikasi keempat tentang regulasi praktik jurnalisme warga. Menurut Macharashvili (2012) ada beberapa pelanggaran yang mencederai praktik jurnalisme warga antara lain: pertama terkait hoax, kualitas berita yang buruk, dan sulit melakukan verifikasi seperti yang terjadi di Kompasiana ada beberapa artikel tidak berkualitas seperti promo buku dan menulis puisi. Selain itu, beberapa hoax yang menyita perhatian beberapa saat terakhir ini di Indonesia, diakibatkan karena banyak orang tidak mampu melakukan verivikasi atas berita yang dibuatnya. Fiedler (2009) menyatakan bahwa tersebarnya hoax begitu mudah melalui teknologi media baru dan ini merupakan salah satu masalah terbesar perwujudan 'democratized' internet.

Pelanggaran kedua yang begitu sering ditemukan terkait dengan profesionalisme terkait tentang isu pemberitaan yang begitu bias dan subjektif. Warga bukanlah profesosional jurnalis yang mendapatkan pelatihan ataupun terliterasi bagaimana menyajikan berita ataupun informasi yang baik dan benar. Akibat yang disampaikan oleh Keen (2007) jika warga yang berperan sebagai jurnalis tidak memiliki pelatihan secara formal akan terus terulang di mana opini menjadi fakta, rumor menjadi berita, dan innuendo (satir) seperti "katanya..." dapat menjadi informasi bukan "faktanya...".

Pelanggaran yang sering terjadi ketiga terkait dengan information overload. Potensi media baru memang mendorong partisipasi warga untuk menuangkan gagasannya dalam bentuk konten berita/ informasi. Namun, potensi ini kemudian menimbulkan overload konten karena tidak adanya peran editor ataupun gatekeeper sebagaimana terdapat pada media arus utama. Seperti pernyataan oleh Keen (2007) 'too many people willing to express their opinions make it more difficult to find the information you need'. Adanya kelebihan information ini membuat batasan fakta, opini, ataupun propaganda sekalipuninisemakin kabur.

Tetapl pada kenyataan belum ada hukum tegas yang mengatur tentang praktik jurnalisme warga. Pada media NET CJ kebijakan pembuatan konten dilengkapi dengan Pedoman Media Siber sehingga, para warga yang ingin membuat berita harus paham betul apa yang tidak boleh dimuat dan apa yang baik untuk dibagikan. Begitu pula Kompasiana yang sebenarnya telah mengatur kebijakan konten, tetapi masih banyak pelanggaran terjadi karena Kompasiana tidak berusaha menyaring kelebihan konten yang menerpa media Kompasiana. Kompasiana baru akan menurunkan artikel berita apabila mendapat laporan dari kompasianer yang lain. Karena belum ada regulasi yang pasti, maka regulasi yang bisa diterapkan pada praktik jurnalisme warga adalah Undangundang ITE agar bijak dalam menyampaikan pendapat di media online.

\section{E. KESIMPULAN}

Tidak diragukan lagi bahwa internet telah memberikan pengaruh besar terhadap perkembangan jurnalisme warga. Media baru dapat dikatakan sebagai jawaban untuk merevitalisasi kembali partisipasi dan kesempatan warga yang telah didominasi 
oleh pemilik modal di media arus utama. Potensi media baru ini juga kemudian membuat media arus utama memperluas jaringannya dalam mengakomodasi partisipasi warga. Tampaknya, kolaborasi yang dilakukan media arus utama dalam mengakomodasi kegiatan jurnalisme warga mampu menimbulkan hubungan simbiosis mutualisme. Institusi media dapat memanfaatkan keberagaman dan kecepatan konten yang diunggah oleh warga negara melalui teknologi media baru hal ini dapat disebut sebagai Hibryd Journalism. Seperti yang terjadi pada Kompasiana dan NET CJ untuk program NET 10. Sedangkan keuntungan bagi warga, mereka dapat turut serta dalam menuangkan gagasan dan konten sebagai wujud demokrasi suatu bangsa.

Kegiatan jurnalisme yang sebelumnya dilakukan oleh wartawan profesional kini dapat dilakukan oleh masyarakat biasa. Pelaporan berita dapat dilakukan oleh masyarakat terkait apa yang mereka alami tanpa literasi dan pelatihan yang cukup. Sehingga banyak yang meragukan sisi jurnalisme dan keakuratannya dalam menyampaikan informasi (Kusumaningati, 2012). Ada beberapa kendala pula terkait praktik jurnalisme warga di Indonesia terutama pada media Kompasiana terkait kredo jurnalisme yang benar tentang objektifitas dan etika sehingga kini masih menjadi perdebatan apakah produk buatan warga ini dapat disebut sebagai produk jurnalistik.

Tidak bisa dipungkiri banyak yang perlu diperhatikan dalam praktik jurnalisme warga di Indonesia. Terlebih, praktik jurnalisme warga kini tidak berhenti sebatas website tetapi juga ke ranah media sosial yang pengaksesnya jauh lebih masif. Bahkan kini jurnalis juga menjadikan berita viral di media sosial sebagai sumber berita. Terpaan informasi akan semakin banyak, dan tentunya semakin sulit membedakan mana berita yang benar. Ini sebenarnya wujud demokrasi, tetapi jangan sampai demokrasi menjadi kebablasan dan menyebabkan perpecahan. Selain itu, di Indonesia sudah saatnya membentuk media warga secara independen dan perlu memberikan literasi ataupun pelatihan kepada pewarta yang berasal dari masyarakat biasa seperti yang dilakukan oleh Oh My News. Dengan demikian warga yang telah terliterasi dengan baik dan mengetahui mana yang layak atau tidak layak diberitakan, akan membangkitkan kekuatan jurnalisme warga Indonesia.

\section{DAFTAR PUSTAKA}

Allan, Stuart 2009. Histories of Citizen Journalism. In: Allan S and Thorsen E (eds) Citizen journalism: Global Perspectives. New York: Peter Lang International Academic Publishers.

Allan, Stuart. 2013. Citizen Witnessing: Key Concepts in Journalism. Cambridge: Polity Press.

Becket, Ch.2010. Super Media: Saving Journalism So It Can Save The World. London: Blackwell Publishing.

Boonlert, Supadhiloke.2014. Citizen Journalism: Empowering Stateless Thais As Citizens, Thammasat Review.

Bowman, S and Willis, C.2003. We Media, How Audiences Are Shaping The Future Of News And Information. In J.D Lasica (Eds). Diakses dari: http://www.hypergene.net/ wemedial

Carr, D. Jasun., Barnidge, Matthew., Lee G. Byung., \& Tsang J. Stephanie. 2014.Cynics And Skeptics: Evaluating The Credibility Of Mainstream And Citizen Journalism. Journalism \& Mass Communication vol. 91 
Cooper, D. Stephen.2006. Watching The Watchdog: Bloggers As The Fifth Estate. Spokane: Marquette Books.

Creeber, Glen and Martin, Royston.2009. Digital Culture Understanding New Media. New York: McGraw Hill.

Fiedler, T.2009. Crisis Alert: Barack Obama Meets Citizen Journalist. In Allan, S And Thoersen (Eds). Citizen Journalism: Global Perspectives. New York: Peter Lang International Academic Publishers.

Glaser, Mark.2006. Your Guide To Citizen Journalism. dari: http://mediashift.org/2006/09/ your-guide-to-citizen-journalism270/

Hermida,A and Thurman, N.2008. A Clash Of Cultures: The Integration Of User-Generated Content Within Professional Journalistic Frameworks At British Newspaper Websites. Journalism Practice 2(3): 343-356.

Jurrat, Nadine.2011. Mapping Digital Media: Citizen Journalism And The Internet. Reference Series Number 4. London: Open Society Foundation.

Keen, Andrew.2007. The Cult Of The Amateur: How Today's Internet Is Killing Our Culture. New York: Doubleday.

Kusumaningati, FR. Imam.2012. Jadi Jurnalis Itu Gampang: Yes, I'm Now A Citizen Journalist. Jakarta: Kompas Gramedia.

Lewis C. Seth., Kaufhold, Kelly., \& Lasorsa L. Dominic.2010.Thinking About Citizen Journalism: The Philosophical And Practical Challenges Of User-Generated Content For Community Newspapers. Journalism Practice 4 .

Macharashvili, Nino.2012. Citizen Journalism And Traditional Media: 5Ws \& H. Washington: University of Warwick.

McChesney, R and Nichols, J.2010. The Death And Life Of American Journalism: The Media Revolution That Will Begin The World Again. New York: Nation Books.

Nichols, L. Sandra., Friedland A. Lewis.,etc. 2006. Examining The Effects Of Public Journalism On Civil Society From 1994 To 2002: Organizational Factors, Project Features, Story Frames, And Citizen Engagement. Journalism \& Mass Communication.

Potts, J. Hartley., Banks, J. Burgess., Cobcroft, R., Cunningham, S., \& Montgomery, L.2008. Consumer Co-Creation And Situated Creativity. Industry and Innovation Volume 5, 459-474. DOI: 10.1080/13662710802373783

Rosen, Jay. 2006. The People Formerly Known As The Audience. Diakses pada 26 Mei 2017 dari: http://archive,pressthink.org/2006/06/27/ppl_frmr.html

Zwick, D., Bonzu, S., \& Darmody, A.2008. Putting Consumers To Work. Journal of Consumer Culture, Volume 2. DOI: 10.1177/1469540508090089.

Referensi lain :

http://www.alexa.com/topsites/countries/ID diakses pada 28 Mei 2017

http://www.kompasiana.com/danielht/rizieq-shihab-juga-pernah-ingatkan-umatnya -jangan-sampai-dibohongi-pakai-ayat-alquran_58215809d27e615f0cf62b3 diakses pada 25 Mei 2017

http://www.kompasiana.com/emnoer_dm70/ahok-memang-menistakan-agama-dimaskanjeng-tidak_57f9b2e1587b61030bca0140 diakses pada 25 Mei 2017 
http://www.kompasiana.com/kompascom/adiknya-di-surga-kebanggaankita_5926614dd57e61750bbd4961 Diakses pada 25 Mei 2017

http://netcj.co.id/unique/video/190257/di-filipina-kuburan-jadi-tempat-wisata-lho Diakses pada 26 Mei 2017

http://netcj.co.id/moment/video/190918/supermarket-di-inggris-juga-ikut-sambutramadan Diakses pada 26 Mei 